\title{
LOCAL IRRIGATION METHODS FOR VEGETABLE PRODUCTION IN SOUTH OF RUSSIA
}

\author{
A.S. Ovchinnikov, E.A. Hodyakov, S.G. Milovanov \\ Volgograd State Agricultural University \\ Universitetskiy pr, 26, Volgograd, 400002, Russian Federation
}

\begin{abstract}
In the Southern Federal District, where the Volgograd region occupies a significant territory, cultivation of vegetable crops is impossible without irrigation. There was a large number of wide-spread sprinklers in the USSR. Each unit of this system watered at least 60 to 70 hectares, required a lot of water pressure that resulted in high operating costs. Therefore, currently, such local irrigation methods as drip and subsoil irrigation have a broad development perspective. Both irrigation methods favorably differ from sprinkling by a significant increase in yield of vegetable crops, irrigation water saving, ease of operation and rapid investment return. In this regard, the main goal of our research, conducted at Volgograd State Agricultural University, is development of techniques and technologies for drip and subsoil irrigation that allow receiving projected vegetable yields while maintaining soil fertility and environmental safety. The research have shown that it is possible to obtain planned yields of 60,70 and 80 t/ha of zucchini and table beet using drip irrigation in steppe zone of southern Russia on light chestnut soils. Therefore, it is necessary to observe irrigation regimes with maintaining pre-irrigation moisture (PIM) $75-85-75$ and $85 \%$ of field moisture capacity (FMC) simultaneously with application of calculated doses of mineral fertilizers. Moreover, it is important to apply increased doses of mineral fertilizers with decrease in intensity of irrigation regime due to reduction in soil moisture content to $75 \%$ of FMC. The planned radish yield of 80 tons per hectare with subsoil irrigation can be obtained in variants with differentiated soil moisture $75-85-75 \%$ of FMC and $1.4 \mathrm{~m}$ distance $\mathrm{n} \mathrm{t}$ between humidifiers, and also maintaining constant soil moisture at $85 \%$ of FMC at plots with 1.2 and $1.4 \mathrm{~m}$ distances.
\end{abstract}

Key words: planned yield, table beet, squash, radish, drip and subsoil irrigation

\section{INTRODUCTION}

In conditions of market relations, in which Russia is today, agricultural producers have lost desire to get the maximum possible yields of vegetable crops. Currently, the main issue is the need to grow such a quantity of products that can be grown considering available water, labor, financial resources [1-3].

In the Southern Federal District, where the Volgograd region occupies a significant territory, cultivation of vegetable crops without irrigation is impossible. In Soviet times, a large number of broad sprinkling equipment was used for this purpose. Each unit of this system watered at least 60 to 70 hectares, required a lot of water pressure, resulting in high operating costs. Therefore, in the present time such local methods of irrigation as drip and subsoil irrigation have a further development perspective [4-7].

Both irrigation methods favorably differ from sprinkling by a significant increase in yield of vegetable crops, irrigation water saving, ease of operation and a rapid investment return. 
So, the main goal of our research was development of drip (DI) and subsoil irrigation (SI) technologies, in order to produce planned crop yields while maintaining soil fertility and environmental safety in conditions of steppe zone of southern Russia.

\section{METHODS AND MATERIALS}

The research was carried out as part of complex long-term field experiments in Research Center "Gornaya Polyana” of Volgograd State Agricultural University.

Irrigation regimes and application of mineral fertilizers were studied in 20022005 to obtain planned yields of 50, 60, 70 tons per hectare of pepper and aubergines, and 70, 80 and 90 tons per hectare of tomatoes under drip irrigation. After that similar studies were carried out in 2012-2014 with zucchini and table beets to produce 60, 70 and $80 \mathrm{t} /$ ha of planned commercial produce under drip irrigation, and in 20142017 - $80 \mathrm{t} / \mathrm{ha}$ of radish using subsoil irrigation.

In field experiments with beets, zucchinis and radish, the main studied crop-forming factor was water regime of soil, which was studied in 3 variants (two permanent and one differentiated). The calculated irrigation rates were given regularly with a decrease in pre-irrigation soil moisture up to set figures.

Two of three-four years of each crop were characterized as arid. This indicated that given yield levels of vegetable crops were obtained even in the most severe weather conditions.

Zucchini 'Nevira' seeds were sown $1.4 \times 0,7 \mathrm{~m}$ apart with drip lines along each row.

Table beet 'Egipetskaya ploskaya' seeds were sown according to the scheme: 4 rows of plants $0.4 \mathrm{~m}$ apart and then — row spacing $0.6 \mathrm{~m}$ wide; plants in a row $-0.10 \ldots 0.12 \mathrm{~m}$ apart; drip lines were placed equidistantly between 1 and 2, 3 and 4 rows.

Black radish was sown in 3 rows $0.45 \mathrm{~m}$ apart, and then - row spacing $0.7 \mathrm{~m}$ wide. After thinning in a row, the plants were left at a distance of $0.08 \mathrm{~m}$ from each other.

Zonal system of vegetable growing was used, with adjustment for water regime maintaining and fertilizer rate in the variants studied.

All observations were made according to well-known procedures [8, 9]. Doses of fertilizers for obtaining planned zucchini yields were calculated according to the methodology of Professor V.I. Filin [10, 11].

The soils of the experimental section are light chestnut, typical for steppe zone of southern Russia and Volga-Don interfluve, characterized by low humus (not more than $1-2 \%$ ) and low nitrate nitrogen content, medium mobile phosphorus and high exchange potassium content.

The DI plot represented a net of Netafim strips (Israel) laid either along or between plant rows. The SI system is a network of polyethylene pipes-humidifiers with point perforations laid at $0.4 \ldots 0.5 \mathrm{~m}$ depth with protective polyethylene film screen on top and bottom along the entire length maintaining uniform moistening of the entire plot area.

\section{RESULTS AND DISCUSSION}

Studies on zucchini under DI showed (Table 1) that when applying calculated doses of mineral fertilizers, planned yields of 60,70 and $80 \mathrm{t} / \mathrm{ha}$ can be obtained only in variants with maintaining pre-irrigation moisture threshold of $75-85-75$ and $85 \%$ of FMC, since in areas with a pre-irrigation moisture of $75 \%$ of FMC deviations from planned yields were more than $10 \%(14.1 \ldots 16.5 \%)$. 
Zucchini yield under drip irrigation (average for 2012-2014)

\begin{tabular}{|c|c|c|c|c|c|c|}
\hline \multicolumn{2}{|c|}{ Yield, t/ha } & \multicolumn{2}{|c|}{ Yield deviations } & \multicolumn{3}{|c|}{ Variants } \\
\hline \multirow[t]{2}{*}{ planned } & \multirow[t]{2}{*}{ actual } & \multirow[t]{2}{*}{$\mathrm{t} / \mathrm{ha}$} & \multirow[t]{2}{*}{$\%$} & \multirow{2}{*}{$\begin{array}{l}\text { Pre-irrigation moisture, } \\
\% \text { of FMC }\end{array}$} & \multicolumn{2}{|c|}{ Fertilizer rate } \\
\hline & & & & & planned yield, $\mathrm{t} / \mathrm{ha}$ & kga.i./ha \\
\hline \multicolumn{7}{|c|}{ initial analysis } \\
\hline \multirow[t]{3}{*}{60} & 50.1 & -9.9 & -16.5 & 75 & \multirow[t]{3}{*}{60} & \multirow{3}{*}{$\mathrm{N}_{180} \mathrm{P}_{75} \mathrm{~K}_{82}$} \\
\hline & 61.0 & +1.0 & 1.7 & $75-85-75$ & & \\
\hline & 62.1 & +2.1 & 3.5 & 85 & & \\
\hline \multirow[t]{3}{*}{70} & 58.4 & -11.6 & -16.6 & 75 & \multirow[t]{3}{*}{70} & \multirow{3}{*}{$\mathrm{N}_{210} \mathrm{P}_{87} \mathrm{~K}_{96}$} \\
\hline & 71.3 & +1.3 & 1.9 & $75-85-75$ & & \\
\hline & 73.0 & +3.0 & 4.3 & 85 & & \\
\hline \multirow[t]{3}{*}{80} & 68.8 & -11.2 & -14.1 & 75 & \multirow[t]{3}{*}{80} & \multirow{3}{*}{$\mathrm{N}_{240} \mathrm{P}_{99} \mathrm{~K}_{110}$} \\
\hline & 82.4 & +2.4 & 3.0 & $75-85-75$ & & \\
\hline & 83.9 & +3.9 & 4.9 & 85 & & \\
\hline \multicolumn{7}{|c|}{ repeated analysis } \\
\hline \multirow[t]{3}{*}{60} & 58.4 & -1.6 & 2.7 & 75 & 70 & $\mathrm{~N}_{210} \mathrm{P}_{87} \mathrm{~K}_{96}$ \\
\hline & 61.0 & +1.0 & 1.7 & $75-85-75$ & \multirow[t]{2}{*}{60} & \multirow{2}{*}{$\mathrm{N}_{180} \mathrm{P}_{75} \mathrm{~K}_{82}$} \\
\hline & 62.1 & +2.1 & 3.5 & 85 & & \\
\hline \multirow[t]{3}{*}{70} & 68.8 & -1.2 & 1.7 & 75 & 80 & $\mathrm{~N}_{240} \mathrm{P}_{99} \mathrm{~K}_{110}$ \\
\hline & 71.3 & +1.3 & 1.9 & $75-85-75$ & \multirow[t]{2}{*}{70} & \multirow{2}{*}{$\mathrm{N}_{210} \mathrm{P}_{87} \mathrm{~K}_{96}$} \\
\hline & 73.0 & +3.0 & 4.3 & 85 & & \\
\hline \multirow[t]{2}{*}{80} & 82.4 & +2.4 & 3.0 & $75-85-75$ & \multirow[t]{2}{*}{80} & \multirow{2}{*}{$\mathrm{N}_{240} \mathrm{P}_{99} \mathrm{~K}_{110}$} \\
\hline & 83.9 & +3.9 & 4.9 & 85 & & \\
\hline
\end{tabular}

Table beet yield under drip irrigation (average for 2012-2014)

Table 2

\begin{tabular}{|c|c|c|c|c|c|c|}
\hline \multicolumn{2}{|c|}{ Yield, t/ha } & \multicolumn{2}{|c|}{ Yield deviations } & \multicolumn{3}{|c|}{ Variants } \\
\hline \multirow[t]{2}{*}{ planned } & \multirow[t]{2}{*}{ actual } & \multirow[t]{2}{*}{ t/ha } & \multirow[t]{2}{*}{$\%$} & \multirow{2}{*}{$\begin{array}{c}\text { Pre-irrigation moisture, } \\
\% \text { of FMC }\end{array}$} & \multicolumn{2}{|c|}{ Fertilizer rate } \\
\hline & & & & & planned yield, t/ha & kg a.i./ha \\
\hline \multicolumn{7}{|c|}{ initial analysis } \\
\hline \multirow[t]{3}{*}{60} & 48.2 & -11.8 & 19.7 & 75 & \multirow[t]{3}{*}{60} & \multirow{3}{*}{$\mathrm{N}_{240} \mathrm{P}_{150} \mathrm{~K}_{105}$} \\
\hline & 57.2 & -2.8 & 4.7 & $75-85-75$ & & \\
\hline & 60.9 & +0.9 & 1.5 & 85 & & \\
\hline \multirow[t]{3}{*}{70} & 58.9 & -11.1 & 15.9 & 75 & \multirow[t]{3}{*}{70} & \multirow[t]{3}{*}{$\mathrm{N}_{280} \mathrm{P}_{175} \mathrm{~K}_{123}$} \\
\hline & 69.6 & -0.4 & 0.6 & $75-85-75$ & & \\
\hline & 73.3 & +3.3 & 4.7 & 85 & & \\
\hline \multirow[t]{3}{*}{80} & 72.8 & -7.2 & 9.0 & 75 & \multirow[t]{3}{*}{80} & \multirow{3}{*}{$\mathrm{N}_{320} \mathrm{P}_{200} \mathrm{~K}_{140}$} \\
\hline & 82.7 & +2.7 & 3.4 & $75-85-75$ & & \\
\hline & 87.1 & +7.1 & 8.8 & 85 & & \\
\hline \multicolumn{7}{|c|}{ repeated analysis } \\
\hline \multirow[t]{3}{*}{60} & 58.9 & -1.1 & 1.8 & 75 & 70 & $\mathrm{~N}_{280} \mathrm{P}_{175} \mathrm{~K}_{123}$ \\
\hline & 57.2 & -2.8 & 4.7 & $75-85-75$ & \multirow[t]{2}{*}{60} & \multirow[t]{2}{*}{$\mathrm{N}_{240} \mathrm{P}_{150} \mathrm{~K}_{105}$} \\
\hline & 60.9 & +0.9 & 1.5 & 85 & & \\
\hline \multirow[t]{3}{*}{70} & 72.8 & +2.8 & 4.0 & 75 & 80 & $\mathrm{~N}_{320} \mathrm{P}_{200} \mathrm{~K}_{140}$ \\
\hline & 69.6 & -0.4 & 0.6 & $75-85-75$ & \multirow[t]{2}{*}{70} & \multirow[t]{2}{*}{$\mathrm{N}_{280} \mathrm{P}_{175} \mathrm{~K}_{123}$} \\
\hline & 73.3 & +3.3 & 4.7 & 85 & & \\
\hline \multirow[t]{2}{*}{80} & 82.4 & +2.4 & 3.0 & $75-85-75$ & \multirow[t]{2}{*}{80} & \multirow{2}{*}{$\mathrm{N}_{320} \mathrm{P}_{200} \mathrm{~K}_{140}$} \\
\hline & 87.1 & +7.1 & 8.8 & 85 & & \\
\hline
\end{tabular}

However, a re-analysis shows that the planned productivity of zucchini of 60 and $70 \mathrm{t} /$ ha can be obtained by maintaining moisture threshold of $75 \%$ of FMC and application of increased doses of fertilizers $-\mathrm{N}_{210} \mathrm{P}_{87} \mathrm{~K}_{96}$ and $\mathrm{N}_{240} \mathrm{P}_{99} \mathrm{~K}_{110}$ with very small deviations from expected yields $(-2.7)$ and $(-1.7) \%$.

The results of three-year field experiments on table beets are shown in Table 2. 
Mineral fertilizer application in calculated doses with irrigation water to DI system helped to obtain planned yield of table beet at the level of 60 and 70 t/ha only in variants with maintenance soil moisture threshold $75-85-75$ and $85 \%$ of $\mathrm{FMC}$, since in plots with a moisture $75 \%$ of FMC deviations from planned yields were $15.9 \%$ and $19.7 \%$, respectively, which was significantly more than $10 \%$.

Repeated analysis shows that these levels of planned table beet yield could be obtained by maintaining moisture threshold of $75 \%$ of FMC and application of increased fertilizer doses $\mathrm{N}_{280} \mathrm{P}_{175} \mathrm{~K}_{123}$ and $\mathrm{N}_{320} \mathrm{P}_{200} \mathrm{~K}_{140}$ with deviations of 1.8 and $4.0 \%$, respectively.

The results obtained are of great practical importance, because of at current price disparity agricultural producer is allowed to plan structure of sown areas based on rising costs of both electricity for supplying irrigation water and mineral fertilizers.

The investigated regimes of zucchini and table beet drip irrigation allow to provide planned yields (Table 3).

In order to maintain a constant less intensive irrigation regime with a moisture threshold of $75 \%$ of FMC, 31 waterings $\left(108 \mathrm{~m}^{3} / \mathrm{ha}\right)$ with irrigation rate of $3348 \mathrm{~m}^{3} / \mathrm{ha}$ were performed in experiments with zucchini: 11 waterings during the interphase periods 'sowing - flowering', 'fruit formation - last harvesting' and 2 waterings less during the period 'flowering — beginning of fruit formation'.

Table 3

Drip irrigation regime for zucchini and beetroot(on average for 2012-2014)

\begin{tabular}{|c|c|c|c|c|c|}
\hline \multirow{3}{*}{$\begin{array}{c}\text { Pre-irrigation } \\
\text { moisture threshold, } \\
\% \text { of FMC }\end{array}$} & \multicolumn{3}{|c|}{ Interphase periods } & \multirow{3}{*}{$\begin{array}{l}\text { Waterings } \\
\text { for season }\end{array}$} & \multirow{3}{*}{$\begin{array}{l}\text { Irrigation } \\
\text { rate, } \\
\mathrm{m}^{3} / \mathrm{ha}\end{array}$} \\
\hline & $\begin{array}{l}\text { sowing - } \\
\text { flowering }\end{array}$ & $\begin{array}{l}\text { flowering - } \\
\text { beginning of fruit } \\
\text { formation }\end{array}$ & $\begin{array}{l}\text { fruit formation - } \\
\text { last harvesting }\end{array}$ & & \\
\hline & \multicolumn{3}{|c|}{ amount of irrigation / irrigation rate $\mathrm{m}^{3} / \mathrm{ha}$} & & \\
\hline \multicolumn{6}{|c|}{ Zucchini } \\
\hline 75 & $11 / 108$ & $9 / 108$ & $11 / 108$ & 31 & 3348 \\
\hline $75-85-75$ & $11 / 108$ & $21 / 54$ & $12 / 108$ & 44 & 3636 \\
\hline 85 & $20 / 54$ & $17 / 54$ & $32 / 54$ & 69 & 3744 \\
\hline \multicolumn{6}{|c|}{ table beet } \\
\hline & $\begin{array}{l}\text { sowing - } \\
\text { beginning of } \\
\text { root formation }\end{array}$ & $\begin{array}{l}\text { root formation - } \\
\text { technical maturity }\end{array}$ & $\begin{array}{c}\text { technical maturity - } \\
\text { harvesting }\end{array}$ & & \\
\hline 75 & $9 / 134$ & $18 / 134$ & $8 / 134$ & 35 & 4690 \\
\hline $75-85-75$ & $9 / 134$ & $47 / 54$ & $8 / 134$ & 64 & 4816 \\
\hline 85 & $25 / 54$ & $49 / 54$ & $27 / 54$ & 101 & 5454 \\
\hline
\end{tabular}

While maintaining a differentiated irrigation regime with a pre-irrigation moisture threshold of $75-85-75 \%$ of FMC irrigation frequency during the season increased to 44 , and irrigation rate - to $3636 \mathrm{~m}^{3} /$ ha due to 11 and 12 irrigation flows of $108 \mathrm{~m}^{3} / \mathrm{ha}$ during periods 'sowing - flowering' and 'fruit formation - last harvesting', respectively, as well as carrying out 21 waterings of $54 \mathrm{~m}^{3} /$ ha in 'flowering — beginning of fruit formation'.

The most intensive irrigation regime with a constant moisture threshold of $85 \%$ of FMC was provided by 69 irrigation cycles $\left(54 \mathrm{~m}^{3} /\right.$ ha) with the highest total irrigation 
water for season of $3744 \mathrm{~m}^{3} / \mathrm{ha}: 20,17$ and 32 irrigation cycles were carried out in 1 , 2 and 3 phase periods of zucchini development, respectively.

In table beet field experiments maintenance of a constant least intensive irrigation regime with an expected moisture threshold of $75 \%$ of FMC was ensured on average by 35 irrigation cycles $\left(134 \mathrm{~m}^{3} / \mathrm{ha}\right.$ ) with irrigation rate of $4690 \mathrm{~m}^{3} /$ ha (higher than in zucchini): 9 irrigations in the interphase period 'sowing — beginning of root formation', 18 during root formation — technical maturity and 8 - in subsequent period before harvesting of root crops.

While maintaining a differentiated irrigation regime with a moisture threshold of $75-85-75 \%$ of FMC, number of irrigations during the season increased to 64 , and the irrigation rate was increased to $4816 \mathrm{~m}^{3} /$ ha due to 47 irrigation operations $\left(54 \mathrm{~m}^{3} / \mathrm{ha}\right)$ during inter-phase period 'sowing — beginning of root formation'.

The most intensive irrigation regime with a constant preliminary moisture threshold of $85 \%$ FMC was achieved by performing 101 irrigations $\left(54 \mathrm{~m}^{3} / \mathrm{ha}\right)$ at the highest irrigation rate of $5454 \mathrm{~m}^{3} / \mathrm{ha:} 25,49$ and 27 irrigations — in the 1st, 2nd and 3rd periods of table beet development, respectively.

The results of field experiments on obtaining the planned radish harvests are shown in Table 4.

In these field experiments, the variants for obtaining a planned yield of $80 \mathrm{t} / \mathrm{ha}$ were investigated while maintaining soil moisture thresholds on the plots with laying of humidifiers in SI system at a distance of 1.2; 1.4 and $1.6 \mathrm{~m}$ apart.

Table 4

Radish yield under subsoil irrigation (average for 2014-2017)

\begin{tabular}{|c|c|c|c|c|c|}
\hline \multicolumn{2}{|c|}{ Yield, t/ha } & \multicolumn{2}{|c|}{ Yield deviations } & \multicolumn{2}{|c|}{ Variants } \\
\hline \multirow[t]{2}{*}{ planned } & \multirow[t]{2}{*}{ actual } & & & \multirow{2}{*}{$\begin{array}{l}\text { Pre-irrigation moisture } \\
\text { threshold, \% of FMC }\end{array}$} & \multirow{2}{*}{$\begin{array}{l}\text { Distance between } \\
\text { humidifiers, m }\end{array}$} \\
\hline & & t/ha & $\%$ & & \\
\hline \multicolumn{6}{|c|}{ initial analysis } \\
\hline \multirow[t]{9}{*}{80} & 59.5 & -20.5 & 25.6 & \multirow[t]{3}{*}{75} & 1.2 \\
\hline & 58.4 & -11.6 & 14.5 & & 1.4 \\
\hline & 53.5 & -26.5 & 33.1 & & 1.6 \\
\hline & 79.3 & -10.7 & 13.4 & \multirow[t]{3}{*}{$75-85-75$} & 1.2 \\
\hline & 78.2 & -1.8 & 2.2 & & 1.4 \\
\hline & 71.0 & -9.0 & 11.2 & & 1.6 \\
\hline & 83.6 & +3.6 & 4.5 & \multirow[t]{3}{*}{85} & 1.2 \\
\hline & 82.2 & +2.2 & 2.8 & & 1.4 \\
\hline & 72.9 & -7.1 & 8.9 & & 1.6 \\
\hline \multicolumn{6}{|c|}{ repeated analysis } \\
\hline \multirow[t]{3}{*}{60} & 58.9 & $\begin{array}{ll}-1.1 \\
\end{array}$ & 1.8 & $75-85-75$ & 1.4 \\
\hline & 57.2 & -2.8 & 4.7 & \multirow[t]{2}{*}{85} & 1.2 \\
\hline & 60.9 & +0.9 & 1.5 & & 1.4 \\
\hline
\end{tabular}

The results obtained showed that such crop yield could be obtained in variants with a differentiated lower soil moisture threshold $75-85-75 \%$ of FMC and $1.4 \mathrm{~m}$ distance between humidifiers, maintaining a constant soil moisture of $85 \%$ of FMC at plots with inter-axis distances of 1.2 and $1.4 \mathrm{~m}$, because of 9 combinations of the factors studied, only these three deviations from planned yield did not exceed $5 \%$. 
Subsoil irrigation regime of radish (average for 2014-2017)

\begin{tabular}{|c|c|c|c|c|c|}
\hline \multirow{3}{*}{$\begin{array}{c}\text { Pre-irrigation } \\
\text { moisture } \\
\text { threshold, } \\
\% \text { of FMC }\end{array}$} & \multicolumn{3}{|c|}{ Interphase periods } & \multirow{3}{*}{$\begin{array}{l}\text { irrigations for } \\
\text { season }\end{array}$} & \multirow{3}{*}{$\begin{array}{l}\text { Irrigation rate, } \\
\mathrm{m}^{3} / \mathrm{ha}\end{array}$} \\
\hline & $\begin{array}{l}\text { sowing - } \\
\text { flowering }\end{array}$ & $\begin{array}{c}\text { flowering - } \\
\text { technical maturity }\end{array}$ & $\begin{array}{c}\text { technical maturity - } \\
\text { harvesting }\end{array}$ & & \\
\hline & \multicolumn{3}{|c|}{ Number of waterings/ irrigation rate, $\mathrm{m}^{3} / \mathrm{ha}$} & & \\
\hline 75 & $1 / 50+3 / 167$ & $6 / 167$ & $5 / 167$ & 15 & 2722 \\
\hline $75-85-75$ & $1 / 50+3 / 167$ & $19 / 100$ & $5 / 167$ & 28 & 3286 \\
\hline 85 & $1 / 50+9 / 100$ & $16 / 100$ & $9 / 100$ & 35 & 3450 \\
\hline
\end{tabular}

Study on similar irrigation regimes for subsoil irrigation is shown in Table 5.

In all variants one sprinkling irrigation $\left(50 \mathrm{~m}^{3} / \mathrm{ha}\right)$ was conducted after radish sowing for better seed germination.

In order to maintain a constant less intensive irrigation regime with moisture threshold $75 \%$ of FMC, 14 vegetative irrigations $\left(167 \mathrm{~m}^{3} / \mathrm{ha}\right)$ with irrigation rate of $2,722 \mathrm{~m}^{3} /$ ha were carried out: 3 vegetative irrigations during interphase period 'sowing - flowering', 6 - in period 'flowering — technical maturity' and 1 watering less during 'technical maturity — harvesting'.

Maintaining differentiated irrigation regime with moisture threshold $75-85-75 \%$ of FMC, number of vegetation irrigations during the season increased to 27 , irrigation rate was increased to $3286 \mathrm{~m}^{3} /$ ha due to increase in irrigation number to $19\left(100 \mathrm{~m}^{3} / \mathrm{ha}\right)$ (instead of $6,167 \mathrm{~m}^{3} / \mathrm{ha}$ ) in period 'flowering — technical maturity'.

The most intensive subsoil irrigation regime of radish with a constant preliminarily humidity threshold $85 \%$ of FMC was achieved by 34 vegetation irrigations $\left(100 \mathrm{~m}^{3} / \mathrm{ha}\right)$ supplying highest total amount of irrigation water of $3450 \mathrm{~m}^{3} /$ ha in season: 9 vegetative irrigations in 1 and 3 radish development phases and 16 waterings - in the second phase.

\section{CONCLUSIONS}

Thus, the studies conducted showed that it is possible to obtain the planned yield of 60, 70 and $80 \mathrm{t} / \mathrm{ha}$ of zucchini and table beet using drip irrigation in steppe zone of southern Russia on light chestnut soils. It is necessary to observe irrigation regimes maintaining preliminary moisture threshold $75-85-75$ and $85 \%$ of FMC with application of calculated doses of mineral fertilizers or to apply higher doses of mineral fertilizers reducing irrigation regime intensity by reducing soil moisture content to $75 \%$ of FMC.

Radish planned yield of $80 \mathrm{t} /$ ha under subsoil irrigation can be obtained in variants with a differentiated soil moisture threshold $75-85-75 \%$ of FMC and $1.4 \mathrm{~m}$ distance between humidifiers, and maintaining a constant soil moisture $85 \%$ of FMC at plots with 1.2 and $1.4 \mathrm{~m}$ interaxial distances.

(C) A.S. Ovchinnikov, E.A. Hodyakov, S.G. Milovanov, 2018. 


\section{REFERENCES}

[1] Ovchinnikov A.S., Gavrilov A.M. Improving efficiency of irrigated farming in arid conditions of south-east of Russia. Izvestiya Nizhnevolzhskogo agrouniversitetskogo kompleksa: nauka $i$ vysshee professional'noe obrazovanie. 2010;(2):5-10. (In Russ).

[2] Ovchinnikov A.S., Bubenchikov M.M., Pakhomov A.A. Status and prospects of land reclamation development in the Volgograd region. Prirodoobustroistvo. 2011;(4):12-15. (In Russ).

[3] Dubenok N.N. Land reclamation is the basis of national agricultural complex improvement. Melioratsiya i vodnoe khozyaistvo. 2013;(3):7-9. (In Russ).

[4] Ovchinnikov A.S., Bocharnikov V.S., Bocharnikova O.V., Meshcheryakov M.P. Innovative irrigation of vegetable crops. Izvestiya Nizhnevolzhskogo agrouniversitetskogo kompleksa: nauka $i$ vysshee professional'noe obrazovanie. 2011;(4):13-17. (In Russ).

[5] Ovchinnikov A.S., Meshcheryakov M.P. The use of resource-saving irrigation methods in crop cultivation. Izvestiya Nizhnevolzhskogo agrouniversitetskogo kompleksa: nauka i vysshee professional'noe obrazovanie. 2007;(1):46-49. (In Russ).

[6] Ovchinnikov A.S., Bocharnikova O.V., Bocharnikov V.S. Assessment of profitability of vegetable production in the Lower Volga Region. Izvestiya Nizhnevolzhskogo agrouniversitetskogo kompleksa: nauka i vysshee professional'noe obrazovanie. 2007;(1):49-53. (In Russ).

[7] Ovchinnikov A.S., Meshcheryakov M.P. Efficiency application and subsurface and drip irrigation systems in the cultivation of sweet pepper. Vestnik Saratovskogo gosagrouniversiteta im. N.I. Vavilova. 2007;(5):74-78. (In Russ).

[8] Dospehov B.A. Metodika polevogo opyta [Methodology of field experiment]. Moscow: Agropromizdat Publ.; 2014. 351 p. (In Russ).

[9] Litvinov S.S. Metodika polevogo opyta v ovoshchevodstve [Technique of field experiment in vegetable growing]. Moscow: Rossel'khozakademiya Publ.; 2011. 650 p. (In Russ).

[10] Filin V.I. Spravochnaya kniga po rastenievodstvu s osnovami programmirovaniya urozhaya [A reference book on plant growing with basics of harvest programming]. Volgograd: VGSKhA Publ.; 1994. 274 p. (In Russ).

[11] Pashkovsky A.I., editor. Sovremennoe ovoshchevodstvo zakrytogo i otkrytogo grunta [Modern vegetable growing in protected and open ground]. Kiev: Kievskaya pravda Publ.; 2006. 528 p. (In Russ).

\section{Author's personal data:}

Alexey Semenovich Ovchinnikov - Doctor of Agricultural Science, Professor, Corresponding Member of the Russian Academy of Sciences, Rector of Volgograd State Agricultural University; e-mail: e419829@yandex.ru

Evgeny Alekseevich Khodyakov - Doctor of Agricultural Science, Professor of Volgograd State Agricultural University; e-mail: e419829@yandex.ru

Sergey Gennadievich Milovanov — PhD Student of Volgograd State Agricultural University; e-mail: e419829@yandex.ru

\section{For citation:}

Ovchinnikov A.S., Hodyakov E.A., Milovanov S.G. Local irrigation methods for vegetable production in south of Russia. Journal of Agronomy and Animal Industries, 2018, 13 (3), 232-240. doi: 10.22363/2312-797X-2018-13-3-232-240. 


\title{
ПОЛУЧЕНИЕ ПЛАНИРУЕМЫХ УРОЖАЕВ ОВОЩНЫХ КУЛЬТУР ПРИ ИСПОЛЬЗОВАНИИ ЛОКАЛЬНЫХ СПОСОБОВ ПОЛИВА НА ЮГЕ РОССИИ
}

\author{
А.С Овчинников, Е.А. Ходяков, С.Г. Милованов \\ ФГБОУ ВО Волгоградский государственный аграрный университет \\ пр. Университетский, 26, Волгоград, 400002, Российская Федераџия
}

В Южном федеральном округе, где Волгоградская область занимает значительную территорию, выращивание овощных культур без орошения невозможно. В советское время для этого использовалось большое количество широкозахватной дождевальной техники. Каждая единица такой техники поливала не менее $60 . .70$ га, требовала большого напора воды и больших эксплуатационных затрат. Поэтому в настоящее время имеют перспективу широкого развития такие локальные способы полива, как капельное и внутрипочвенное орошение. Оба способа полива выгодно отличаются от дождевания значительным повышением урожайности овощных культур, экономией оросительной воды, простотой эксплуатации и быстрой окупаемостью вложенных затрат. В связи с этим основной целью наших исследований, проводимых в Волгоградском государственном аграрном университете, является разработка техники и технологий капельного и внутрипочвенного орошения, позволяющих получать планируемые урожаи овощных культур при сохранении почвенного плодородия и экологической безопасности. Проведенные исследования показали, что в степной части юга России на светло-каштановых почвах можно получать планируемую урожайность 60,70 и 80 т/га кабачков и столовой свеклы при проведении капельного орошения. Для этого необходимо соблюдать режимы орошения с поддержанием предполивного порога влажности 75-85-75 и 85\% НВ одновременно с внесением расчетных доз минеральных удобрений. Либо необходимо вносить повышенные дозы минеральных удобрений при снижении интенсивности поливного режима за счет уменьшения предполивной влажности почвы до $75 \%$ НВ. Планируемую урожайность 80 т/га редьки при внутрипочвенном поливе можно получить на вариантах с дифференцированным нижним порогом влажности почвы $75-85-75 \%$ HB и расстоянием между увлажнителями 1,4 м, а также при поддержании постоянной предполивной влажности почвы $85 \% \mathrm{HB}$ на участках с расстояниями 1,2 и 1,4 м.

Ключевые слова: планируемая урожайность, столовая свекла, кабачки, редька, капельное и внутрипочвенное орошение

\section{БИБЛИОГРАФИЧЕСКИЙ СПИСОК}

[1] Овчинников A.C. Повышение эффективности орошаемого земледелия в засушливых условиях юго-востока России / Овчинников А.С., Гаврилов А.М // Известия Нижневолжского агроуниверситетского комплекса: наука и высшее профессиональное образование. 2010. № 2. C. 5-10.

[2] Овчинников А.C. Состояние и перспективы развития мелиорации в Волгоградской области / Овчинников А.С., Бубенчиков М.М., Пахомов А.А. // Известия Нижневолжского агроуниверситетского комплекса: наука и высшее профессиональное образование. 2011. № 4. С. $12-15$.

[3] Дубенок Н.Н. Мелиорация - основа успешного агроиндустриального комплексного развития // Мелиорация и водное хозяйство. 2013. № 3. С. 7-9.

[4] Овчинников А.С. Инновационные технологии орошения овощных культур / Овчинников А.С., Бочарников В.С., Бочарникова О.В., Мещеряков М.П // Известия Нижневолжского агроуниверситетского комплекса: наука и высшее профессиональное образование. 2011. № 4. C. 15-17. 
[5] Овчинников А.С. Применение ресурсосберегающих способов полива при возделывании сельскохозяйственных культур / Овчинников А.С., Мещеряков М.П // Известия Нижневолжского агроуниверситетского комплекса: наука и высшее профессиональное образование. 2007. № 1. С. 46- 49.

[6] Овчинников А.С. Оценка рентабельности производства овощей в Нижнем Поволжье / Овчинников А.С., Бочарникова О.В., Бочарников В.С // Известия Нижневолжского агроуниверситетского комплекса: наука и высшее профессиональное образование. 2007. № 1. C. $49-53$.

[7] Овчинников А.С. Эффективность применения и конструкции систем внутрипочвенного и капельного орошения при возделывании сладкого перца / Овчинников А.С., Мещеряков М.П. // Известия Нижневолжского агроуниверситетского комплекса: наука и высшее профессиональное образование. 2007. № 5. С. 74-78.

[8] Доспехов Б.А. Методика полевого опыта. М.: Агропромиздат, 2014.

[9] Литвинов С.С. Методика полевого опыта в овощеводстве. М.: Россельхозакадемия, 2011.

[10] Филин В.И. Справочная книга по растениеводству с основами программирования урожая. Волгоград: ВГСХА, 1994.

\section{Для цитирования:}

Овчинников А.С., Ходяков Е.А., Милованов С.Г. Получение планируемых урожаев овощных культур при использовании локальных способов полива на юге России // Вестник Российского университета дружбы народов. Серия: Агрономия и животноводство. 2018. Т. 13. № 3. С. 232240. doi: 10.22363/2312-797X-2018-13-3-232-240. 